\title{
CHGA wt Allele
}

National Cancer Institute

\section{Source}

National Cancer Institute. CHGA wt Allele. NCI Thesaurus. Code C52403.

Human CHGA wild-type allele is located in the vicinity of $14 \mathrm{q} 32$ and is approximately $12 \mathrm{~kb}$ in length. This allele, which encodes chromogranin A protein, is involved in the modulation of the neuroendocrine system. 